\title{
PERBAIKAN SIFAT FISIKA DAN KIMIA TANAH PADA TANAH BEKAS TAMBANG INTAN DI CEMPAKA DENGAN METODE COMPOSTING BERBAHAN DASAR KOTORAN SAPI
}

\author{
PHYSICAL AND CHEMICAL SOIL PROPERTIES IMPROVEMENT ON POST-DIAMOND MINING \\ SOIL IN CEMPAKA USING COMPOSTING METHOD BASED ON COW DUNG
}

\author{
Demetrius Natanael ${ }^{1}$, Muhammad Firmansyah ${ }^{2}$ dan Andy Mizwar $^{3}$ \\ Program Studi Teknik Lingkungan, Fakultas Teknik, Universitas Lambung Mangkurat, JL. A. Yani Km. \\ 36 Banjarbaru, Kalimantan Selatan, 70714, Indonesia \\ E-mail: muhammad.firmansyah@ulm.ac.id
}

\begin{abstract}
ABSTRAK
Penelitian ini bertujuan untuk mengidentifikasi kondisi suhu, pH dan kelembapan pada bioremediasi metode composting, mengidentifikasi perubahan sifat fisika dan kimia tanah bekas tambang intan sebelum dan sesudah proses composting berbahan dasar kotoran sapi. Penelitian ini dilakukan secara open windrow dengan empat variasi komposisi yaitu A (100\% tanah) sebagai kontrol, B (75\% tanah : $25 \%$ kompos), $C$ (50\% tanah : $50 \%$ kompos), $D(25 \%$ tanah : $75 \%$ kompos $)$ dan lama waktu composting yaitu 30 hari. Metode analisis yang digunakan dalam mengolah data menggunakan software Microsoft Excel dan SPSS 17.0. Hasil penelitian suhu, pH dan kelembapan keempat perlakuan selama proses bioremediasi dengan metode composting mengalami fluktuasi. Berdasarkan hasil uji $T$ terdapat perbedaan nilai $C$-organik, $N$-total, Rasio $C / N$, dan KTK sebelum dan sesudah proses composting. Hasil Uji LSD 5\% variasi komposisi terbaik yang mampu memperbaiki kualitas tanah tambang adalah variasi komposisi D yaitu $25 \%$ tanah : $75 \%$ kompos.
\end{abstract}

Kata kunci: komposting, bioremediasi, open windrow

\begin{abstract}
This research discusses about changing the temperature, $\mathrm{pH}$, and humidity in the composting bioremediation method, changing the physical and chemical properties of the former diamond mining soil before and after the composting process based on cow dung. This research was conducted openly windrow with variations in composition A (100\% soil) as a control, B (75\% soil: $25 \%$ compost), C (50\% soil: $50 \%$ compost), D (25\% soil: $75 \%$ compost) ) and composting time is 30 days. The analytical method used in processing data uses Microsoft Excel and SPSS 17.0 software. The results of the study of temperature, $\mathrm{pH}$ and humidity of four stages during the bioremediation process with composting methods increase fluctuations.. Based on the results of the $C$-organic value, $N$-total, $C$ / $N$ ratio, and CEC before and after the composting process. LSD Test Results 5\% The best variation of composition that can improve the quality of mine soil is the variation of composition D, which is $25 \%$ soil: $75 \%$ compost.
\end{abstract}

Keywords: composting, bioremediation, open windrow 


\section{PENDAHULUAN}

Penambangan intan yang dilakukan di Kelurahan Sungai Tiung Kecamatan Cempaka sejak beberapa tahun yang lalu dilakukan dengan membuka tanah permukaan kemudian dilanjutkan dengan menggali tanah bagian bawahnya untuk mengambil hasil tambang berupa intan, namun setelah dilakukan penambangan, bagian tanah atasnya (top soil) tidak dikembalikan lagi seperti semula. Hal ini menyebabkan banyaknya lubang-lubang besar disekitar area penambangan dan membuat banyak danau-danau yang dikelilingi tanah bekas kerukan disekitarnya. Menurut penelitian yang dilakukan (Indriyatie, 2011) bahwa tumpukan tanah dari hasil galian bekas tambangdapat menurunkan kualitas fisika dan kimia dari tanah tersebut. Hasil uji pendahuluan yang dilakukan pada bulan Februari 2019 pada sampel tanah bekas galian tambang intan Cempaka menunjukkan nilai KTK 8,03me/100g, kandungan C-organik dan $\mathrm{N}$-total yang rendah serta warna tanah yang berwarna merah kekuningan. Berdasarkan kriteria kesesuaian lahan menurut Peraturan Menteri Pertanian No. 79 Tahun 2013 tanah tambang intan di Cempaka tidak sesuai dengan kriteria dan dapat dikatakan kurang subur dan miskin unsur hara.

Kotoran sapi merupakan bahan yang sangat potensial yang dapat dimanfaatkan untuk dijadikan pupuk organik. Kebutuhan akan pupuk organik akan meningkat seiring dengan tingginya permintaan akan ketersediaan bahan ataupun produk yang organik. Hal ini juga disebabkan makin tingginya kesadaran bahwa bahan organik lebih sehat, lebih enak, dan lebih baik bagi lingkungan (Huda, 2017). Menurut penelitian yang dilakukan oleh (Trivana, 2017) bahwa kotoran sapi yang dimanfaatkan untuk dijadikan pupuk memiliki kandungan nitrogen $(\mathrm{N})$, fosfor $(\mathrm{P})$, dan kalium (K) dan kandungan lainnya seperti kalsium, magnesium, belerang, natrium, besi dan juga tembaga sebagai unsur hara mikro.

Berdasarkan latar belakang tersebut peneliti akan melakukan penelitian untuk memperbaiki sifat fisika dan kimia tanah pada tanah bekas tambang intan di Kecamatan Cempaka menggunakan metode Composting berbahan dasar kotoran sapi.

\section{METODE PENELITIAN}

Penelitian dilaksakan pada bulan Mei sampai bulan Juli 2019. Adapun Lokasi-lokasi yang digunakan sebagai tempat penelitian ini adalah contoh tanah bekas tambang intan di Kecamatan Cempaka. Bioremediasi dengan metode composting dilakukan di ETP Fakultas Teknik ULM. Tempat pengujian sampel pupuk kompos dan sampel tanah dilakukan di Pusat Penelitian Lingkungan Hidup Universitas Lambung Mangkurat.

Alat dan bahan yang digunakan dalam penelitian ini adalah tanah bekas tambang $300 \mathrm{~kg}$, kompos setengah matang $180 \mathrm{~kg}$, sekop, cangkul, timbangan analitik, karung goni, terpal, trash bag, timbangan, soil survey instrument, soil tester, rak box, kamera sebagai alat dokumentasi penelitian, alat tulis, dan alat-alat lainnya yang menunjang penelitian ini.

Rancangan penelitian menggunakan Rancangan Acak Lengkap (RAL) dengan 4 perlakuan dan 3 ulangan. Perlakuan yang dimaksud yaitu A (100\% tanah) sebagai kontrol, B (75\% tanah : 25\% kompos), C (50\% tanah : 50\% kompos), D (25\% tanah : $75 \%$ kompos) dengan berat masing-masing satu perlakuan/tumpukan $40 \mathrm{~kg}$. Ukuran masing-masing tumpukan sama dengan tinggi $30 \mathrm{~cm}$ dan jarak antar tumpukan yaitu $30 \mathrm{~cm}$. 
Proses composting dilakukan selama kurang lebih 30 hari. Pengukuran suhu, $\mathrm{pH}$ dan kelembapan dilakukan setiap hari pada pukul 13.00 - 14.00 WITA di beberapa titik pada tumpukan yaitu pada tiga titik (atas, tengah, bawah) menggunakan alat soil survey instrument dan soil tester. Data hasil penelitian disajikan dalam bentuk grafik untuk mengidentifikasi kondisi $\mathrm{pH}$, suhu dan kelembapan.

Data yang diperoleh dari analisis laboratorium dibuat tabel kemudian dilakukan uji T, uji One Way Anova dan uji LSD 5\% menggunakan software SPSS 17.0 for windows untuk melihat perbedaan variasi komposisi terbaik pada composting sistem open windrow dan mengidentifikasi variasi komposisi terbaik pada composting berbahan dasar kotoran sapi. Adapun hasil yang didapat tersebut berasal dari data awal pada proses composting sebelum perlakuan dan setelah perlakuan dalam jangka waktu 30 hari.

\section{HASIL DAN PEMBAHASAN}

\subsection{Kondisi Bioremediasi dengan Metode Composting}

Grafik perubahan suhu kompos dengan perlakuan variasi A (100\% tanah) sebagai kontrol, B (75\% tanah : $25 \%$ kompos), C (50\% tanah : 50\% kompos), D (25\% tanah : 75\% kompos) dapat dilihat pada Gambar 1.

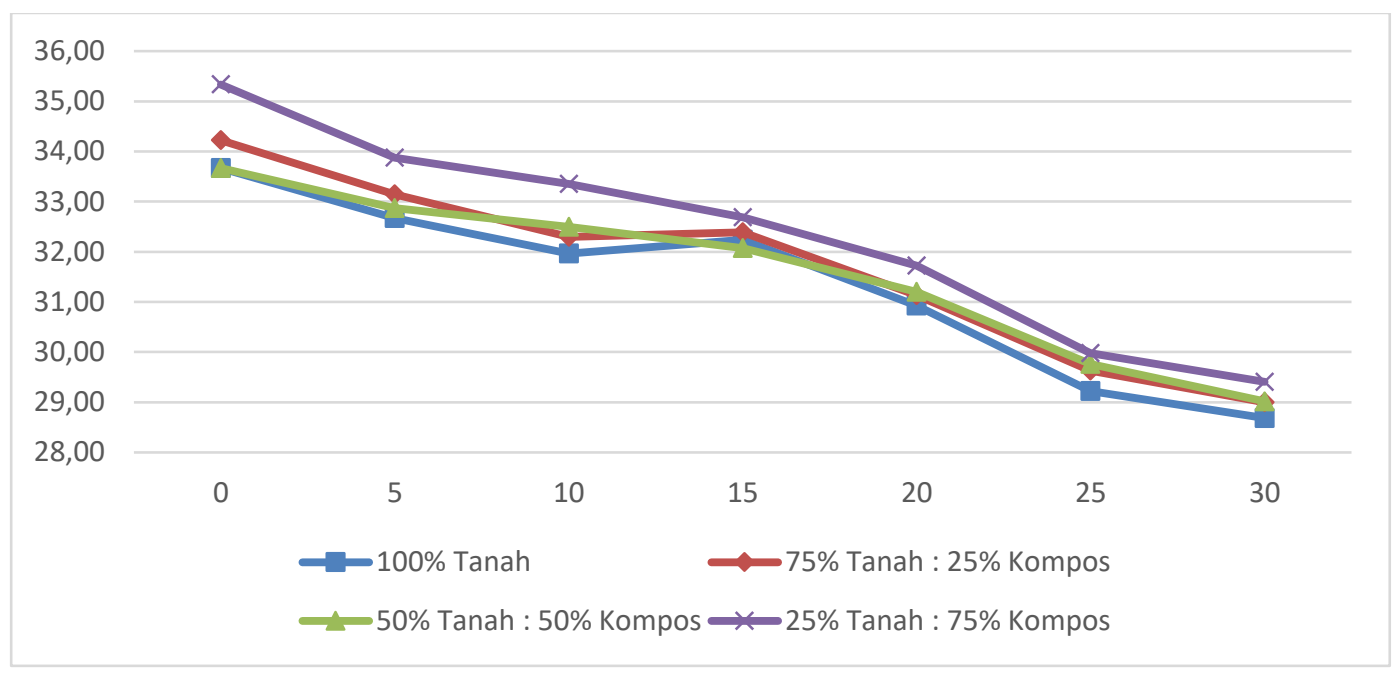

Gambar 1. Grafik Perubahan Suhu Rata-rata per 5 Hari

Hasil pengamatan pada Gambar 1 menunjukkan suhu selama proses composting mengalami penurunan. Hal ini menunjukkan proses degradasi mulai menurun akibat berkurangnya bahan karbon organik yang terurai menjadi gas $\mathrm{CO}_{2}$, air, dan panas (kalor). Selama proses composting keempat perlakuan menunjukkan nilai suhu berkisar antara $29-35^{\circ} \mathrm{C}$, yang berarti bahwa mikroorganisme yang bekerja adalah mikroorganisme mesofilik. Mikroorganisme mesofilik berfungsi untuk memperkecil ukuran partikel bahan organik (Rhys dkk, 2016). Kondisi mesofilik lebih efektif karena aktivitas mikroorganisme didominasi protobakteri dan fungi. Suhu pada masing-masing perlakuan tidak mencapai fase termofilik dikarenakan tumpukan bahan yang terlalu rendah akan membuat bahan lebih cepat kehilangan panas, sehingga temperatur yang tinggi tidak dapat tercapai (Widarti dkk, 2015) 
Hasil pengamatan perubahan suhu tertinggi yang diambil berdasarkan rata-rata dari semua tumpukan yaitu berada pada hari ke-0 pada variasi $25 \%$ tanah : $75 \%$ kompos dengan suhu $35^{\circ} \mathrm{C}$. Pengukuran suhu diambil dari 3 titik yaitu atas, tengah, dan bawah tumpukan. Pada saat pengukuran, suhu di titik atas tumpukan rata-rata lebih tinggi daripada di titik bagian tengah dan bawah. Sedangkan suhu terendah yang didapat adalah di hari ke-30 pada variasi $100 \%$ tanah yaitu $29^{\circ} \mathrm{C}$.

Grafik perubahan pH kompos dapat dilihat pada Gambar 2.

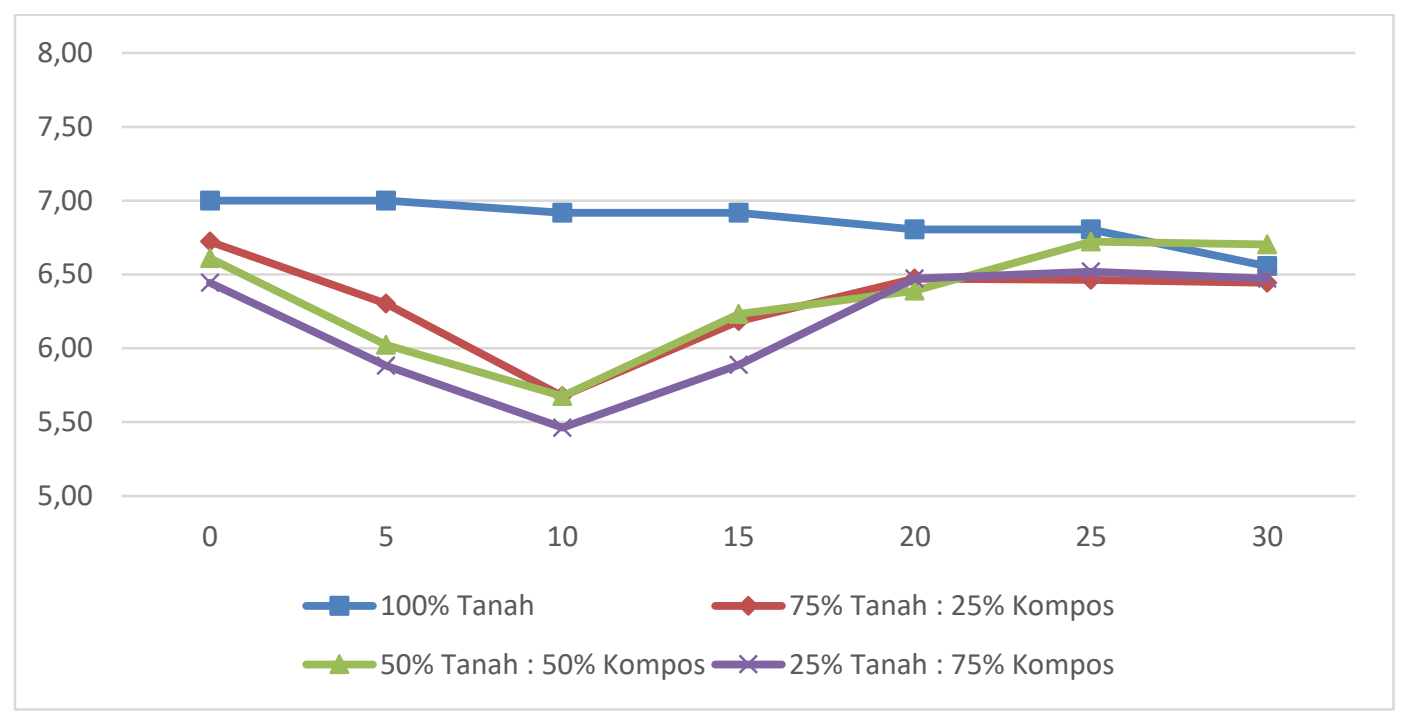

Gambar 1. Grafik Perubahan pH Rata-rata per 5 Hari

Perubahan $\mathrm{pH}$ selama pengomposan seperti pada Gambar 2 menunjukkan bahwa selama proses pengomposan $\mathrm{pH}$ perlakuan $100 \%$ tanah mengalami penurunan yaitu $\mathrm{pH}$ pada hari ke- 0 sampai hari ke-25 adalah 7 (netral) dan pada hari ke-25 sampai hari ke-30 pH menurun menjadi 6,5 (kearah asam). Penurunan nilai $\mathrm{pH}$ saat pengomposan disebabkan oleh aktivitas mikroorganisme yang menghasilkan asam organik dan reduksi dari ion ammonium (NH4+) (Suwatanti dan Widiyaningrum, 2017). Nilai $\mathrm{pH}$ perlakuan 25\% tanah : 75\% kompos mengalami peningkatan yaitu pada 10 hari pertama terjadi penurunan dari 7 (netral) menurun menjadi 5,6 (kearah asam), kemudian meningkat pada 20 hari terakhir pengomposan menjadi 6,5 (netral). Perubahan $\mathrm{pH}$ untuk perlakuan 50\% tanah : 50\% kompos mengalami penurunan dari 6,6 (netral) menjadi 5,6 (kearah asam) dari hari ke-0 sampai dengan hari ke-10, kemudian mengalami kenaikan dari hari ke-10 hingga hari ke-30 dari pH 5,6 (kearah asam) menjadi 6,6 (netral) . Nilai pH pada perlakuan 75\% tanah : $25 \%$ kompos juga mengalami penurunan, tetapi tidak terlalu signifikan yaitu dari 5,8 menjadi 6,0 .

Kadar air (kelembaban) menjadi salah satu faktor yang berperan penting dalam proses composting, karena secara tidak langsung akan berpengaruh pada suplai oksigen. Hal tersebut dapat terjadi apabila kandungan air terlalu rendah atau tinggi akan mengurangi efisiensi proses pengomposan. Kadar air yang optimal adalah sekitar 50-60\%. Apabila kadar air kurang dari 50\% maka pengomposan akan berlangsung lambat, namun bila kadar air melebihi $60 \%$ menyebabkan unsur hara dan volume udara dalam kompos berkurang. Kompos tidak boleh terlalu lembab maupun terlalu kering. 
Grafik perubahan kadar air dapat dilihat pada Gambar 3.

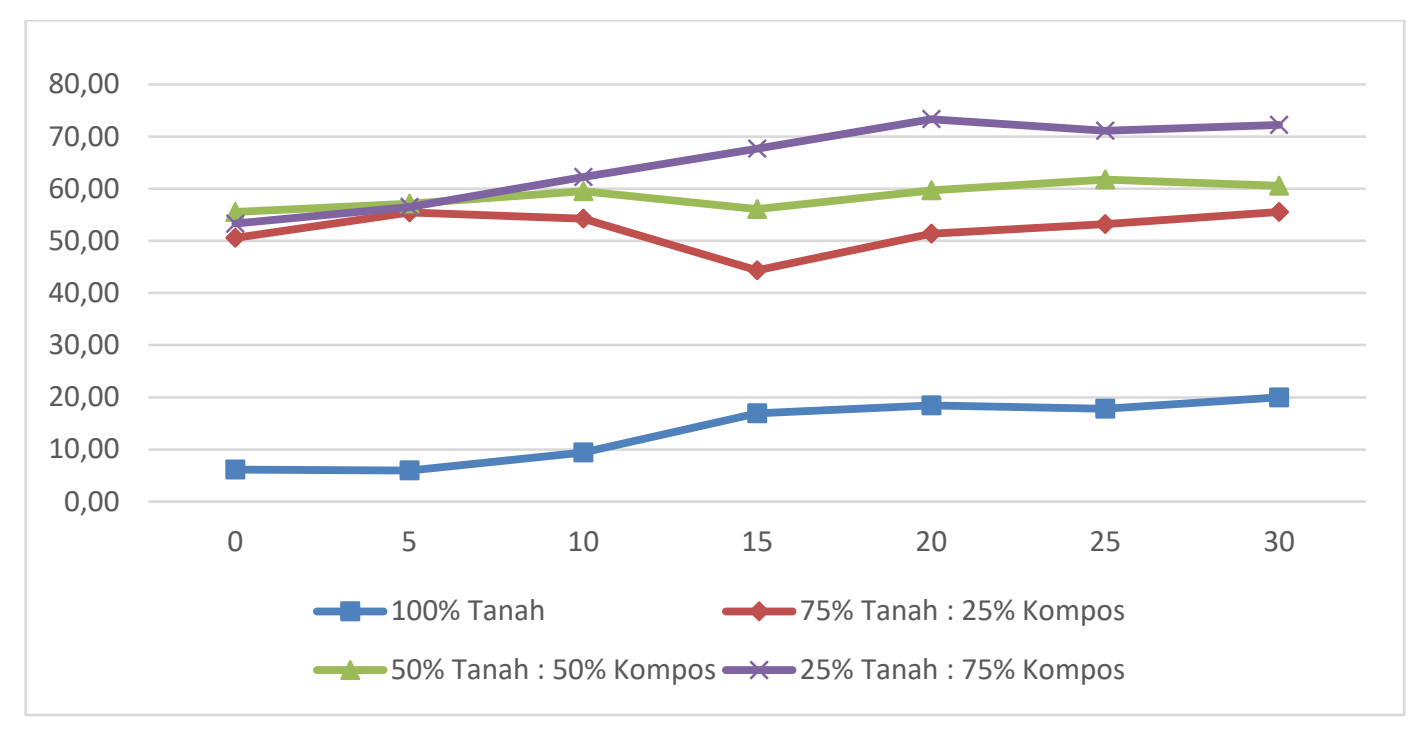

Gambar 2. Grafik Perubahan Kelembaban Rata-rata per 5 Hari

Hasil pengamatan pada Gambar 3 menunjukkan bahwa kelembapan perlakuan $100 \%$ tanah pada hari ke-0 hingga hari ke-30 kadar air mengalami kenaikan yaitu dari 6\% menjadi 20\%. Pada perlakuan $25 \%$ tanah : 75\% kompos kadar air berkisar antara $44-55 \%$ dan pada perlakuan ini masih dalam kondisi kelembapan optimum untuk pengomposan aerob yaitu 50-60\%, sementara pada perlakuan 50\% tanah : 50\% kompos kadar air berkisar antara 57-61\% dan perlakuan 75\% tanah : $25 \%$ kompos kadar air berkisar antara 55-72\% dari hari ke-0 hingga hari ke-30. Kelembapan pada perlakuan 50\% tanah : 50\% kompos dan 75\% tanah : 25\% kompos tersebut melebihi kondisi kelembapan optimum untuk pengomposan aerob yaitu 50-60\% (Suwatanti dan Widiyaningrum, 2017).

Kondisi kelembapan lebih besar dari $60 \%$ akan mencegah oksigen berpindah melalui masa bahan, sehubungan dengan porositas yang terjadi dipenuhi oleh air sehingga ruang udara bebas menjadi tidak ada. Juanda dkk (2011) dalam (Suwatanti dan Widiyaningrum, 2017), juga mengatakan bahwa jika tumpukan kompos terlalu lembab maka proses dekomposisi akan berjalan lambat. Hal ini dikarenakan kandungan air akan menutupi rongga udara di dalam tumpukan. Kondisi ini akan menyebabkan proses pengomposan akan berlangsung lebih lama.

\subsection{Warna Tanah pada Composting}

Hasil pengamatan (Tabel 1) menunjukkan bahwa warna tumpukan pada kontrol dan pada komposisi 25\% tanah : $75 \%$ kompos tidak mengalami perubahan yang berarti sebelum maupun sesudah proses composting. Namun pada tanah yang diberi perlakuan kompos memberi perubahan warna. Rata-rata warna tanah berubah menjadi coklat gelap dan kehitaman menandakan kesuburan tanah tambang meningkat, tetapi lama waktu proses composting tidak berpengaruh nyata terhadap warna tanah. Pengaruh proses composting terhadap warna tanah tambang disajikan pada Tabel 1. 
Tabel 1 Warna Sebelum dan Sesudah Composting

\begin{tabular}{lll}
\hline Perlakuan & \multicolumn{1}{c}{ 0 (sebelum) } & \multicolumn{1}{c}{ 30 (sesudah) } \\
\cline { 2 - 3 } A (100\% tanah) & Cokelat (7.5 YR 4/6) & Cokelat kekuningan(7.5 YR 5/8) \\
B (75\% tanah + 25\% kompos) & Cokelat gelap (10 YR 2/4) & Cokelat gelap (10 YR 2/4) \\
C (50\% tanah + 50\% kompos) & Cokelat kehitaman (10 YR 2/3) & Cokelat kehitaman (10 YR 1/2) \\
D (25\% tanah + 75\% kompos) & Cokelat Kehitaman (2.5 Y 1/2) & Hitam (5 YR 1/1) \\
\hline
\end{tabular}

Keterangan: YR yaitu yellow red

Hal ini sesuai dengan penelitan Sunuk dkk. (2018) pemberian kompos pada tanah tambang yang awalnya berwarna cokelat menjadi warna hitam. Tanah yang diberikan bahan organik berfungsi memberikan warna gelap atau kehitaman dengan manfaat sebagai indikasi tanah menjadi subur. Makin tinggi kandungan bahan organik yang dicampurkan, maka warna tanah semakin gelap (Margolang dkk, 2015). Tanah dengan kualitas baik umumnya berwarna coklat gelap, yang umumnya berhubungan dengan kandungan bahan organik dan kesuburan yang relatif tinggi (Saidy, 2018).

\subsection{C-Organik pada Composting}

Pengaruh proses composting terhadap C-organik tanah tambang dapat dilihat pada Tabel 2.

Tabel 1 Nilai C-organik Sebelum dan Sesudah Composting

\begin{tabular}{cccc}
\hline \multirow{2}{*}{ Perlakuan } & \multicolumn{2}{c}{ C-organik (\%) } & $\begin{array}{c}\text { Kriteria Menurut Permentan } \\
\text { No. 79 Tahun 2013 }\end{array}$ \\
\cline { 2 - 3 } & 0 hari (sebelum) & 30 hari (sesudah) & \\
\hline A (100\% tanah) & 0.58 & 0.92 & $\mathrm{~S} 1>1,2$ \\
B (75\% tanah $+25 \%$ kompos) & 4.15 & 1.02 & $\mathrm{~S} 20,8-1,2$ \\
C (50\% tanah $+50 \%$ kompos) & 4.47 & 0.78 & $\mathrm{~S} 3<0,8$ \\
D (25\% tanah $+75 \%$ kompos) & 5.42 & 0.69 & \\
\hline
\end{tabular}

Hasil uji T (Lampiran C) menunjukkan terdapat perbedaan nilai C-organik antara sebelum dan sesudah proses composting. Namun setelah tanah diberi perlakuan kompos Dapat dilihat pada Tabel 2 C-organik semua perlakuan sesudah proses composting mengalamai penurunan. Irawan dkk (2016) mengatakan bahwa penurunan C-organik disebabkan karena pada proses dekomposisi bahan organik dirombak menjadi senyawa anorganik sehingga kadar C-organik menurun. Nilai C-organik untuk perlakuan $\mathrm{C}$ dan $\mathrm{D}$ sudah sesuai dengan kriteria kesuaian lahan menurut Peraturan Menteri Pertanian No.79 Tahun 2013 yaitu pada kriteria kesesuaian lahan kategori S3, sementara pada perlakuan A dan B termasuk dalam kategori S2.

Berdasarkan uji Anova (Lampiran C) perlakuan pemberian kompos di tanah tambang menunjukkan tidak ada perbedaan rata-rata $(\mathrm{sig}>0.05)$ setelah perlakuan terhadap perubahan nilai C-organik tanah tambang. Perubahan C-organik tanah setelah proses composting dapat dilihat di Gambar 4. 


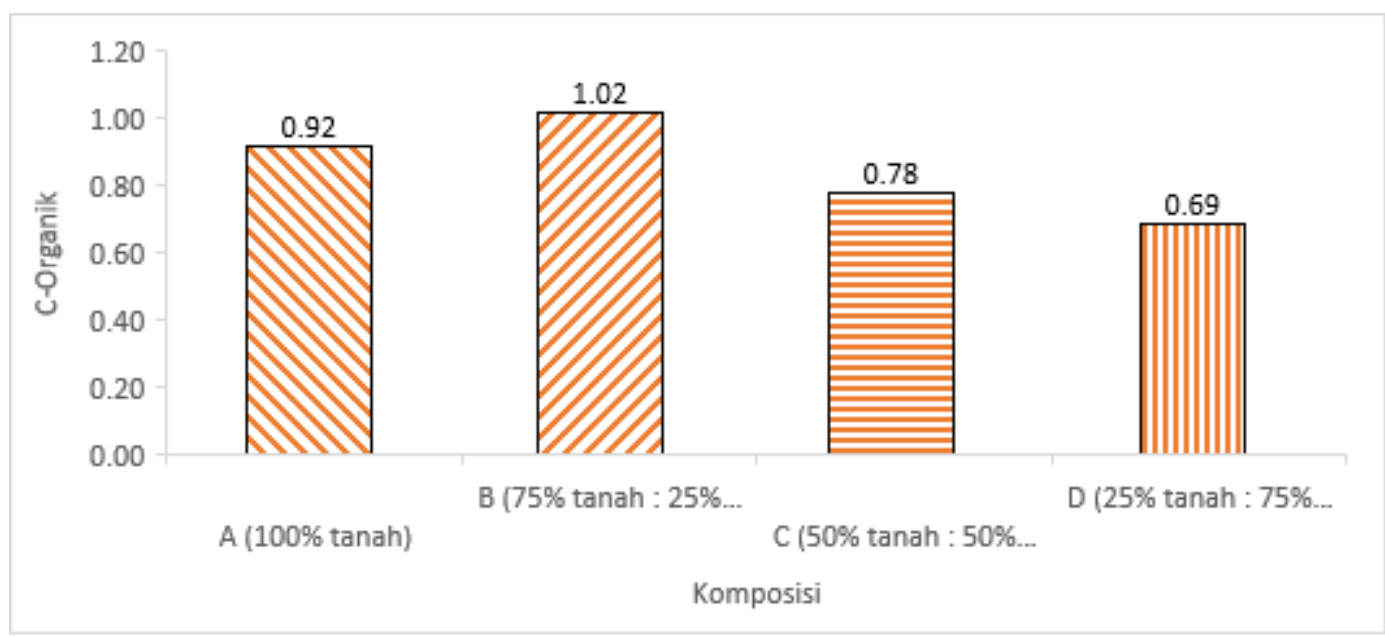

Gambar 4. Nilai C-organik pada Variasi Komposisi dan Hasil Uji LSD 5\%

Terjadi penurunan C-Organik pada perlakuan C dan D dibandingkan dengan perlakuan A sebagai kontrol. Hal tersebut terjadi karena selama proses pengomposan karbon digunakan oleh mikroorganisme untuk pertumbuhan dan sebagai sumber energi. Kadar air dan kadar karbon organik mempunyai hubungan berbanding negatif/ terbalik Dimana kadar air meningkat, maka kandungan karbon organik menurun. Sehingga pada variasi kadar air $40 \%$ memiliki kecederungan C-organik lebih tinggi dibandingkan dengan variasi kadar air 60\% (Kurnia, 2017). Hal ini sesuai dengan pengamatan penelitian bahwa perlakuan B, C dan D memiliki kelembapan yang lebih besar dibandingkan dengan komposisi perlakuan A.

\subsection{N-Total pada Composting}

Pengaruh proses composting terhadap N-total tanah tambang dapat disajikan pada Tabel 3.

Tabel 2. Nilai N-total Sebelum dan Sesudah Composting

\begin{tabular}{|c|c|c|c|}
\hline \multirow{2}{*}{ Perlakuan } & \multicolumn{2}{|c|}{ N-total (\%) } & \multirow{2}{*}{$\begin{array}{c}\text { Kriteria Menurut } \\
\text { Permentan No. } 79 \\
\text { Tahun } 2013\end{array}$} \\
\hline & 0 hari (sebelum) & 30 hari (sesudah) & \\
\hline A $(100 \%$ tanah $)$ & 0.17 & 0.20 & \multirow{4}{*}{$\begin{array}{l}\text { S1 Sedang }(0,16-0,50) \\
\text { S2 Rendah }(0,01-0,15) \\
\text { S3 Sangat Rendah } \\
(<0,01)\end{array}$} \\
\hline B $(75 \%$ tanah $+25 \%$ kompos $)$ & 0.20 & 0.23 & \\
\hline $\mathrm{C}(50 \%$ tanah $+50 \%$ kompos $)$ & 0.29 & 0.16 & \\
\hline $\mathrm{D}(25 \%$ tanah $+75 \%$ kompos $)$ & 0.45 & 0.36 & \\
\hline
\end{tabular}

Hasil Uji T menunjukkan tidak terdapat perbedaan nilai $\mathrm{N}$-total antara sebelum dan sesudah proses composting. Hasil penelitian (Tabel 3) menunjukkan N-total pada perlakuan A dan B mengalami peningkatan setelah proses composting dan perlakuan lainnya menurun. Peningkatan kadar nitrogen terjadi karena proses dekomposisi yang dilakukan mikroorganisme yang menghasilkan ammonia dan nitrogen. Hal tersebut terjadi karena peningkatan kadar nitrogen dapat terjadi karena padatan tervolatil atau bahan organik yang terdegradasi lebih besar dibandingkan NH3 yang tervolatilisasi. Penurunan kadar nitrogen disebabkan oleh nitrogen yang bereaksi dengan air membentuk NO3- dan 
H+ (Trivana dan Pradhana, 2017). Nilai N-total yang sesuai dengan kriteria kesesuaian lahan untuk pertanian menurut Peraturan Menteri Pertanian No 79 Tahun 2013 terdapat pada semua variasi komposisi dan menunjukkan bahwa semua variasi masuk kedalam kategori S1 (sedang).

Berdasarkan uji Anova bahwa perlakuan pemberian kompos pada tanah tambang menunjukkan berpengaruh nyata terhadap perubahan nilai N-total tanah tambang. Kemudian karena uji Anova ( sig<0,05) maka dilanjutkan dengan uji LSD 5\%. Hasil uji LSD 5\% variasi komposisi 25\% tanah : 75\% kompos (Komposisi D) memberikan perbedaan nyata bila dibandingkan dengan perlakuan lainnya. Perubahan C-organik tanah setelah proses composting dapat dilihat pada Gambar 5.

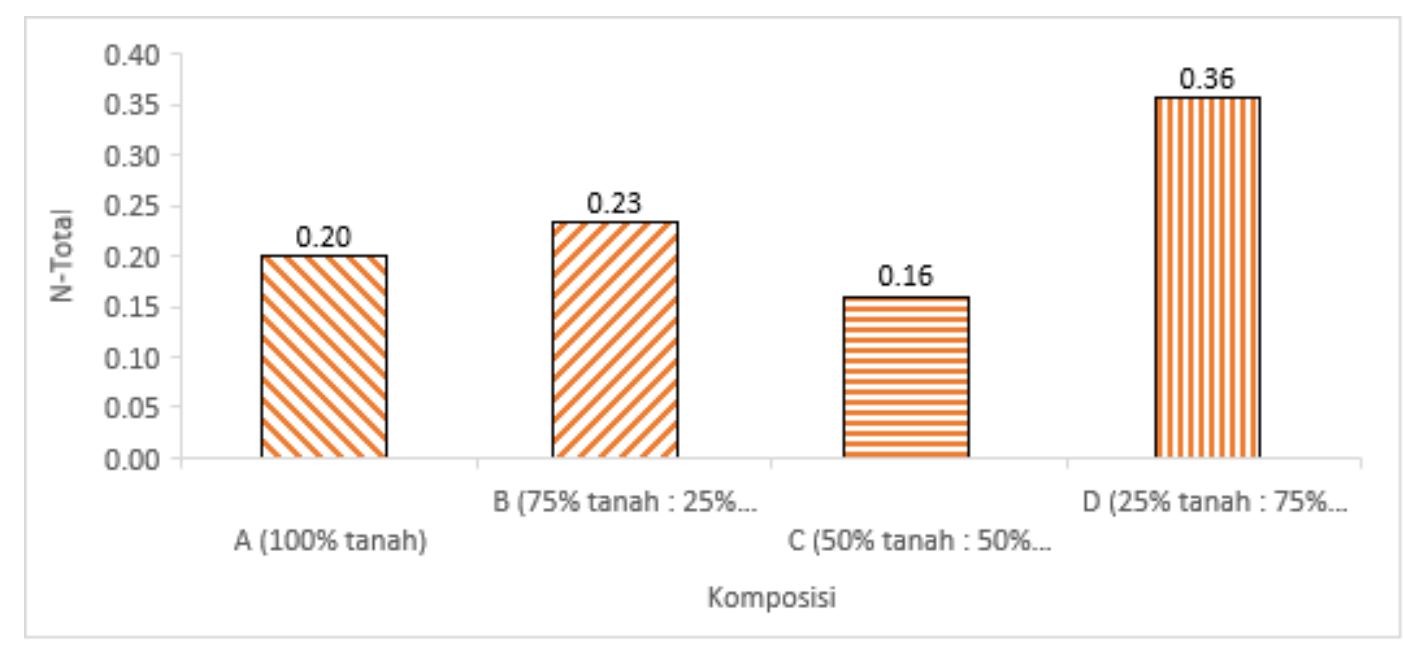

Gambar 3. Nilai N-total pada Variasi Komposisi dan Hasil Uji LSD 5\%

Perlakuan kontrol sebesar $0,20 \%$. Kemudian setelah tanah diberi perlakuan kompos terjadi sedikit peningkatan berkisar 0,22\% - 0,35\%. Hal ini sejalan dengan penelitian Sukartono dkk (2017) bahwa peningkatan kadar $\mathrm{N}$ dalam tanah disebabkan oleh peningkatan kandungan bahan organik dalam tanah. Salah satu sumber N dalam tanah yaitu berasal dari bahan organik. Afandi (2015) menjelaskan bahwa proses hilangnya $\mathrm{N}$ yang ada di dalam tanah dapat disebabkan karna diserap oleh tanaman, digunakan oleh mikroorganisme.

\subsection{Rasio C/N pada Composting}

Pengaruh proses composting terhadap Rasio C/N tanah tambang dapat disajikan pada Tabel 4.

Tabel 3. Nilai Rasio C/N Sebelum dan Sesudah Composting

\begin{tabular}{lll}
\hline \multirow{2}{*}{ Perlakuan } & Rasio C/N \\
\cline { 2 - 3 } & 0 hari (sebelum) & 30 hari (sesudah) \\
\hline A (100\% tanah) & 3.38 & 4.62 \\
B (75\% tanah + 25\% kompos) & 21.21 & 4.53 \\
C (50\% tanah + 50\% kompos) & 15.69 & 4.91 \\
D (25\% tanah + 75\% kompos) & 12.18 & 2.06 \\
\hline
\end{tabular}


Hasil Uji $\mathrm{T}$ menunjukkan terdapat perbedaan nilai rasio $\mathrm{C} / \mathrm{N}$ antara sebelum dan sesudah proses composting. Nilai rasio $\mathrm{C} / \mathrm{N}$ dapat dilihat (Tabel 4.4) sesudah pengomposan mengalami penurunan pada perlakuan B, C dan D. Menurut Widarti dkk (2015) penurunan nilai rasio C/N pada masingmasing perlakuan ini disebabkan karena terjadinya penurunan jumlah karbon yang dipakai sebagai sumber energi mikroba untuk menguraikan atau mendekomposisi material organik.

Berdasarkan uji Anova bahwa perlakuan pemberian kompos pada tanah tambang menunjukkan berpengaruh sangat nyata $($ sig $<0,05)$ terhadap perubahan nilai $\mathrm{N}$-total tanah tambang, sehingga dilanjutkan ke uji LSD 5\%. Hasil uji LSD 5\% Rasio C/N variasi komposisi 25\% tanah : 75\% kompos (Komposisi D) memiliki perbedaan nyata bila dibandingkan dengan perlakuan lainnya. Perubahan rasio $\mathrm{C} / \mathrm{N}$ tanah setelah proses composting dapat dilihat pada Gambar 6 .

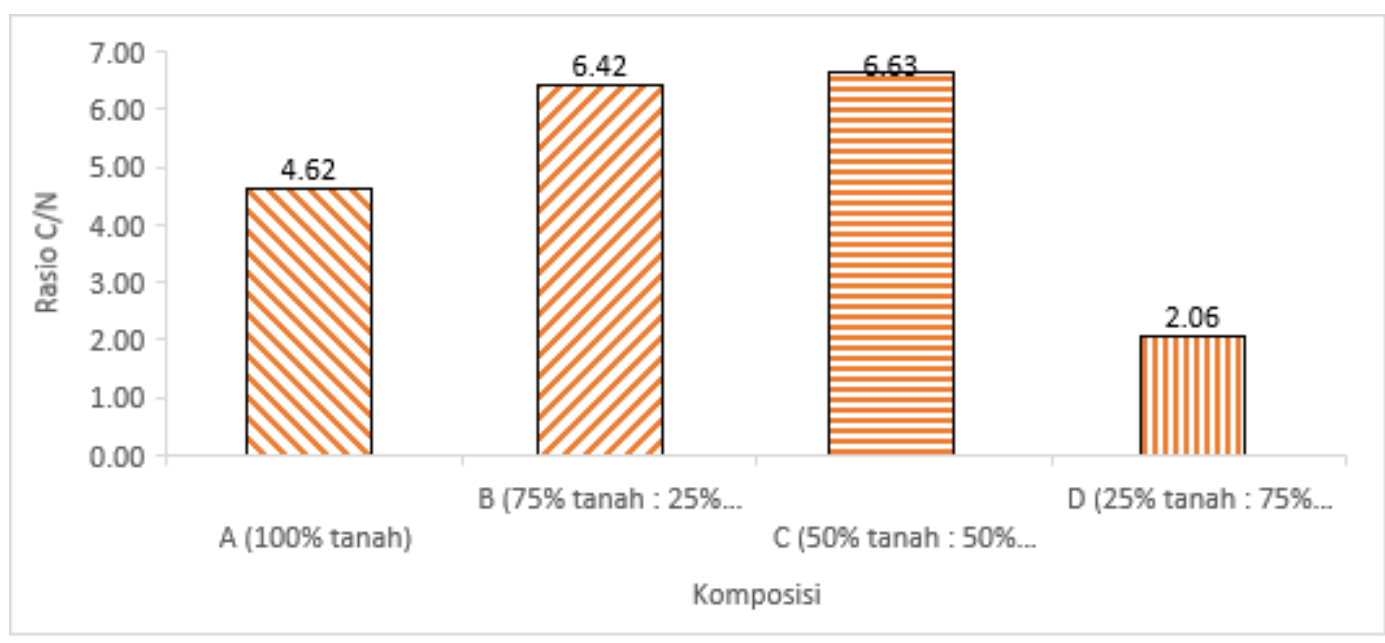

Gambar 4. Nilai Rasio C/N pada Variasi Komposisi dan Hasil Uji LSD 5\%

Variasi komposisi 50\% tanah : 50\% kontrol memiliki nilai rasio $\mathrm{C} / \mathrm{N}$ tertinggi dibandingkan perlakuan lainnya yaitu sebesar 6,63. Nilai rasio $\mathrm{C} / \mathrm{N}$ setelah pengomposan menurut kriteria penilaian sifat kimia tanah menurut Hardjowigeno (1995) tergolong rendah. Menurut Rhys dkk (2016) perbandingan $\mathrm{C} / \mathrm{N}$ yang rendah menunjukkan bahwa proses mineralisasi berjalan dengan baik, ketersediaan unsur hara tinggi dan tanaman dapat memenuhi kebutuhan hidupnya.

\subsection{KTK pada Composting}

Pengaruh proses composting terhadap KTK tanah tambang dapat disajikan pada Tabel 5.

Tabel 4. Nilai KTK Tanah Sebelum dan Sesudah Composting

\begin{tabular}{|c|c|c|c|}
\hline \multirow[b]{2}{*}{ Perlakuan } & \multicolumn{2}{|c|}{ KTK (me/100g) } & \multirow{2}{*}{$\begin{array}{l}\text { Kriteria Menurut } \\
\text { Permentan No. } 79 \text { Tahun } \\
2013\end{array}$} \\
\hline & $\begin{array}{l}\text { O hari } \\
\text { (sebelum) }\end{array}$ & $\begin{array}{l}30 \text { hari } \\
\text { (sesudah) }\end{array}$ & \\
\hline A $(100 \%$ tanah $)$ & 14.69 & 9.93 & \multirow{4}{*}{$\begin{array}{l}\mathrm{S} 1>16 \\
\mathrm{~S} 25-16 \\
\mathrm{~S} 3<5\end{array}$} \\
\hline B $(75 \%$ tanah $+25 \%$ kompos $)$ & 15.02 & 12.71 & \\
\hline$C(50 \%$ tanah $+50 \%$ kompos $)$ & 16.20 & 14.56 & \\
\hline $\mathrm{D}(25 \%$ tanah $+75 \%$ kompos $)$ & 18.06 & 27.10 & \\
\hline
\end{tabular}


Hasil uji T menunjukkan tidak terdapat perbedaan nilai KTK antara sebelum dan sesudah proses composting. Namun setelah tanah diberi perlakuan kompos terjadi peningkatan nilai KTK pada perlakuan D. Mengacu pada kriteria kesesuaian lahan menurut Permentan No.79 Tahun 2013 yang sesuai dengan kriteria S1 yaitu variasi komposisi $25 \%$ tanah : $75 \%$ kompos, sementara komposisi A, B dan C berada pada kategori S2.

Berdasarkan Uji Anova bahwa perlakuan pemberian kompos pada tanah tambang memberikan pengaruh yang berbeda nyata terhadap KTK tanah. Kemudian karena uji Anova $(\operatorname{sig}<0,05)$ maka dilanjutkan dengan uji LSD 5\%. Hasil uji LSD 5\% menunjukkan peningkatan C-organik terhadap variasi komposisi kompos dan tanah tambang dibandingkan kontrol. Perubahan KTK tanah setelah proses composting dapat dilihat pada Gambar 7.

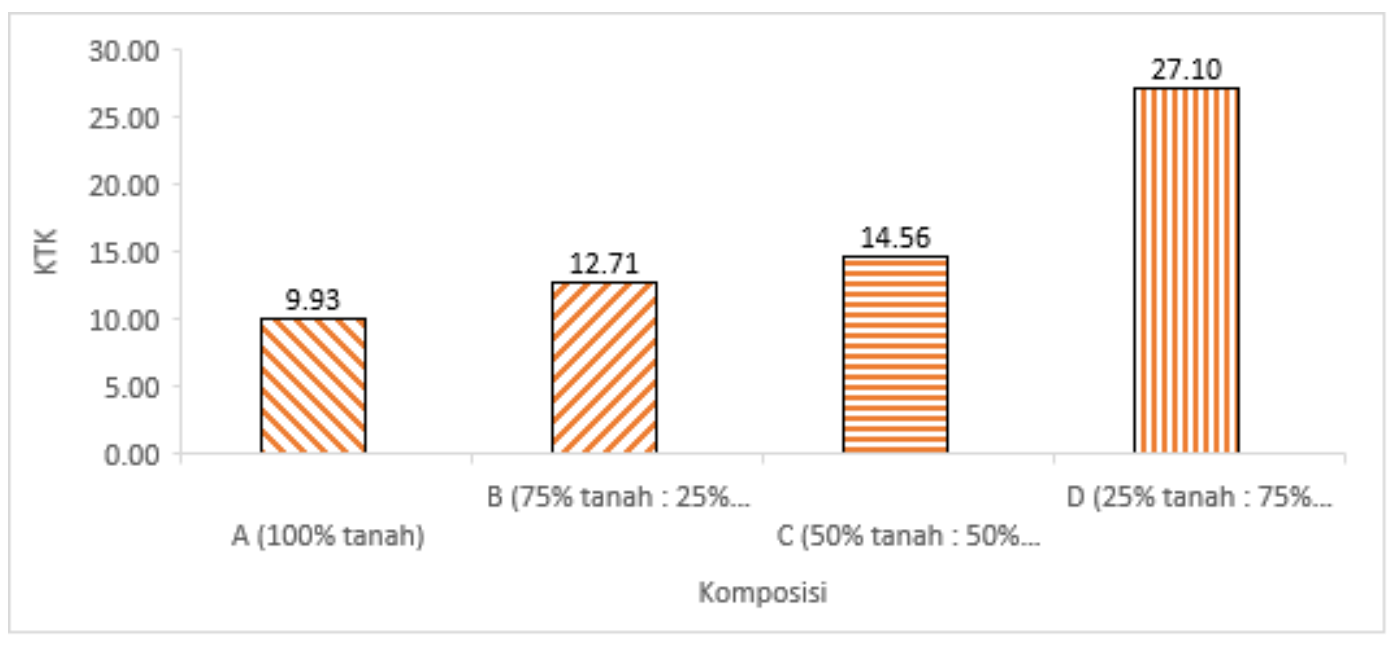

Gambar 5. Nilai KTK pada Variasi Komposisi dan Hasil Uji LSD 5\%

Nilai KTK tertinggi terdapat pada variasi komposisi 25\% tanah : 75\% kompos dan sangat berbeda nyata dengan variasi komposisi lainnya . Hasil pengamatan (Gambar 7) nilai KTK tanah mengalami peningkatan setelah diberi perlakuan kompos. Hal ini sejalan dengan penelitian Alibasyah (2016) pemberian perlakuan kompos mampu meningkatkan KTK tanah.

Peningkatan KTK tidak terlepas dari pemberian kompos yang berfungsi memperbaiki KTK. Sejalan dengan pendapat Stevenson (1992) dalam Alibasyah (2016), bahwa bahan organik memberikan konstribusi yang nyata terhadap peningkatan kapasitas tukar kation sekitar 20-70\% yang bersumber pada koloid humus. Sukartono dkk (2017) juga mengatakan bahwa faktor yang mempengaruhi KTK adalah kandungan bahan organik dan kadar liat. Tanah dengan kandungan bahan organik dan kadar liat tinggi memiliki KTK lebih tinggi dibandingkan dengan tanah yang mempunyai kadar bahan organik rendah dan berpasir.

Berdasarkan penelitian yang dilakukan kondisi suhu keempat perlakuan selama proses composting mengalami penurunan. Suhu pada proses pengomposan hanya mencapai fase mesofilik karena suhu tertinggi pengomposan hanya mencapai $37^{\circ} \mathrm{C}$ pada rata-rata 5 hari pertama. Selama pengomposan $\mathrm{pH}$ mengalami kenaikan dan penurunan. Fluktuasi nilai $\mathrm{pH}$ merupakan penanda terjadinya aktivitas mikroorganisme dalam menguraikan dan mendegradasi bahan organik (Suwatanti dan Widiyaningrum, 2017). Kelembapan juga mengalami fluktuasi selama proses pengomposan. Kadar 
air akan sangat berpengaruh dalam mempercepat terjadinya perubahan dan penguraiaan bahanbahan organik yang digunakan dalam proses composting (Widarti dkk, 2015).

Tanah yang diberi perlakuan kompos sebelum atau sesudah proses composting dapat merubah warna tanah menjadi tanah berubah menjadi gelap atau kehitaman dan mampu meningkatkan nilai C-organik, N-total, Rasio C/N dan KTK tanah menjadi sesuai berdasarkan kriteria kesesuaian lahan menurut Peraturan Menteri Pertanian No. 79 Tahun 2013. Berdasarkan hasil uji $\mathrm{T}$ terdapat perbedaan nilai C-organik, N-total, Rasio C/N, KTK serta warna sebelum dan sesudah proses composting. Hasil Uji LSD 5\% variasi komposisi terbaik yang mampu memperbaiki kualitas tanah tambang adalah variasi komposisi 25\% tanah : 75\% kompos (komposisi D).

\section{KESIMPULAN}

Suhu keempat perlakuan selama proses bioremediasi dengan metode composting mengalami penurunan, $\mathrm{pH}$ pada semua variasi komposisi mengalami kenaikan dan penurunan, sementara kelembapan mengalami kenaikan pada semua perlakuan, terjadinya fluktuasi antara suhu, $\mathrm{pH}$ dan kelembapan dikarenakan adanya aktivitas mikroorganisme selama pengomposan. Tanah yang diberi perlakuan kompos sebelum atau sesudah proses composting dapat merubah warna tanah menjadi gelap atau kehitaman dan mampu meningkatkan nilai C-organik, N-total, Rasio C/N dan KTK tanah menjadi sesuai berdasarkan kriteria kesesuaian lahan menurut Peraturan Menteri Pertanian No. 79 Tahun 2013. Berdasarkan hasil uji T terdapat perbedaan nilai C-organik, N-total, Rasio C/N, KTK serta warna sebelum dan sesudah proses composting. Hasil Uji LSD 5\% variasi komposisi terbaik yang mampu memperbaiki kualitas tanah tambang adalah variasi komposisi $25 \%$ tanah : $75 \%$ kompos (komposisi D).

\section{DAFTAR PUSTAKA}

Alibasyah, M.R. 2016. Perubahan Beberapa Sifat Fisika Dan Kimia Ultisol Akibat Pemberian Pupuk Kompos Dan Kapur Dolomit Pada Lahan Berteras. J. Floratek, 11(1).

Huda, S., Wikanta, W. 2017. Pemanfaatan Limbah Kotoran Sapi Menjadi Pupuk Organik Sebagai Upaya Mendukung Usaha Peternakan Sapi Potong di Kelompok Tani Ternak Mandiri Jaya Desa Moropelang Kec. Babat Kab. Lamongan. Jurnal Pengabdian Kepada Masyarakat, 1(1), 26-53.

Indrayatie, E, R. 2011. Dampak Pasca Penambangan Intan Terhadap Kualitas Tanah Dan Air di Kelurahan Palam,Kecamatan Cempaka Kota Banjarbaru Kalimantan Selatan. Jurnal Hutan Tropis, 12(31), 15-25.

Kurnia, V.C., S. Sumiyati dan G. Samudro. 2017. Pengaruh Kadar Air Terhadap Hasil Pengomposan Sampah Organik Dengan Metode Open Windrow. Jurnal Teknik Mesin, 6.

Peraturan Menteri Pertanian nomor : 51/Permentan/OT.140/9/2010 Tentang Pedoman Umum Pemulihan Kesuburan Lahan Tahun Anggaran 2010.

Sunuk, Y., Montolalu, M., Tamod, Z.E. Aplikasi Kompos Sebagai Pembenah pada Bahan Induk Tanah Tambang Emas di Desa Tatelu Kecamatan Dimembe. Jurnal Ilmiah, 1(1), 1-15.

Suwatanti, E.P.S., Widiyaningrum, P. 2017. Pemanfaatan MOL Limbah Sayur pada Proses Pembuatan Kompos. Jurnal MIPA, 40(1), 1-6. 
Trivana, L., Pradhana, A, Y. 2017. Optimalisasi Waktu Pengomposan dan Kualitas Pupuk Kandang dari Kotoran Kambing dan Debu Sabut Kelapa dengan Bioaktivator PROMI dan Orgadec. Jurnal Sain Veteriner, 35(1).

Widarti, B.N., Wardhini, W.K, Sarwono, E. 2015. Pengaruh Rasio C/N Bahan Baku pada Pembuatan Kompos dari Kubis dan Kulit Pisang. Jurnal Integrasi Proses, 5(2), 75-80. 